\title{
Regulation of lipid synthesis in relation to keratinocyte differentiation capacity
}

\author{
Maria Ponec ${ }^{a}$, Johanna Kempenaar ${ }^{a}$ and Johannes Boonstra ${ }^{b}$ \\ ${ }^{a}$ Department of Dermatology, University Hospital, Leiden, and ${ }^{b}$ Department of Molecular Cell Biology, University \\ of Utrecht, Utrecht (The Netherlands)
}

(Received 8 December 1986)

(Revised manuscript received 25 March 1987)

Key words: Lipid synthesis; Lipoprotein; Differentiation; (Human epidermal keratinocyte)

Cultured keratinocytes and squamous carcinoma cells provide a useful model system for studying the processes involved in the regulation of differentiation, as the differentiation capacity of the cells can be modulated experimentally by changing the extracellular calcium concentration. Furthermore, the squamous carcinoma cell lines exhibit a defect in their differentiation capacity which they express to different extents. In this paper, the effect of external lipoproteins has been studied on lipid synthesis in normal keratinocytes and three squamous carcinoma cell (SCC) lines which showed a decreasing capacity to differentiate in the order of normal keratinocytes $>$ SCC-12F2 $>$ SCC-15 $>$ SCC-4. The ability of the cells to form cornified envelopes was taken as a measure of differentiation capacity. The rate of total lipid synthesis as well as the phospholipid-neutral lipid ratio decreased in the order SCC-4 $>$ SCC-15 $>$ SCC-12F2 $\geq$ normal keratinocytes, clearly correlating with the differentiation capacity of the cells. Because of the high rate of phospholipid synthesis and the low rate of ceramide synthesis, it is concluded that, under these in vitro conditions used, the maturation of keratinocytes proceeds to a lesser extent than that seen under in vivo conditions. In proliferating cells, in which the low-density lipoprotein (LDL) receptor is operative to a high extent, the rate of lipogenesis, especially that of neutral lipids, responded dramatically to changes of extracellular lipoprotein concentration. In the presence of lipoproteins a marked decrease of cholesterol and triacylglycerol synthesis and an increase of cholesterol ester synthesis has been observed. On the other hand, in differentiating cells lipogenesis appeared to be independent of extracellular lipoproteins, due to the absence of the LDL uptake mechanism, the only exception being the synthesis of triacylglycerols, the rate of which could be modulated to a certain extent by extracellular lipoproteins. The results presented here demonstrate a close inverse relationship between the regulation of lipogenesis by extracellular lipoproteins and the ability of the cells to differentiate.

Introduction

The composition and dynamic properties of the

\footnotetext{
Abbreviations: SCC, squamous carcinoma cell, LDL, low-density lipoprotcins.

Correspondence: Dr. M. Ponec, Department of Dermatology, University Hospital, P.O. Box 9606, 2300 RC Leiden, The Netherlands.
}

plasma membrane are believed to play a central role in the regulation of cellular proliferation and differentiation. In particular, cholesterol has been identified as a key component. Thus, for example, it has been demonstrated that the cholesterol content increases during differentiation and, as a consequence, also changes in microviscosity, and lateral mobility of lipids and proteins have been observed [1]. 
A similar relationship has been demonstrated recently in cultured keratinocytes [2]. Cholesterol depletion, using inhibitors of cholesterol biosynthesis, resulted in a decreased cholesterol/ phospholipid ratio in the plasma membrane and coincidently also in a decreased capacity of the cells to form cornified envelopes [3]. Since most cell types, in addition to synthesizing cholesterol, are able to obtain cholesterol by uptake from external lipoproteins (in particular from low-density lipoprotein [4]), the I.DL-regulated cholesterol supply has been studied in keratinocytes [5-8]. During differentiation of the cells, a decrease in LDL-receptor expression and LDL metabolism was observed, accompanied by an increase in de novo cholesterol biosynthesis [9].

Cultured keratinocytes provide a useful model system for studying epidermal differentiation, as the differentiation capacity of the cells is dependent upon the external $\mathrm{Ca}^{2+}$ concentration [10-12]. Lowering the $\mathrm{Ca}^{2+}$ concentration to levels below $0.1 \mathrm{mM}$ caused a reduction in the differentiation capacity of normal human keratinocytes and a variety of transformed human keratinocyte cell lines [8,13-16]. This regulatory role of $\mathrm{Ca}^{2+}$ might occur in vitro, as well as in vivo [17]. In addition, a number of squamous carcinoma cell (SCC) lines have been demonstrated to exhibit a differential defect in differentiation capacity $[18,19]$. In these cells a reciprocal correlation has also been found between the capacity to differentiate on the one hand and LDL-receptor expression, LDL metabolism and associated cholesterol biosynthesis on the other [6].

In order to obtain better insight into the possible relationship between plasma membrane composition and differentiation capacity of keratinocytes, we have studied lipid synthesis in normal keratinocytes and various SCC lines in more detail. Since cholesterol synthesis is dependent upon the presence of external lipoproteins, lipid synthesis was measured in both lipoprotein-deficient and lipoprotein-containing media, in the presence of low (proliferating) or normal (differentiating) external $\mathrm{Ca}^{2+}$ concentrations. It is demonstrated that the initiation of differentiation is associated with the loss of the response of lipogenesis towards changes of extracellular lipoproteins.

\section{Materials and Methods}

\section{Cell lines and culture conditions}

Juvenile human epidermal keratinocytes (first to fourth passage) and SCC lines were cultured using the Rheinwald-Green feeder layer technique [20]. The SCC lines were kindly provided by Dr. J.G. Rheinwald $[18,19]$. The cells were cultured in a Inixlure of Dulbecco-Vogt and Ham's F12 medium $(3: 1)$ supplemented with $5 \%$ fetal calf serum, $0.4 \mu \mathrm{g} / \mathrm{ml}$ hydrocortisone (SCC lines), $10^{-6} \mathrm{M}$ isoproterenol and $10 \mathrm{ng} / \mathrm{ml}$ epidermal growth factor (normal keratinocytes). For the low-calcium cultures calcium-free Dulbecco-Vogt medium mixed with standard Ham's F12 medium $(3: 1)$ and supplemented with $5 \%$ chelex-treated fetal calf serum [21] was used. The final calcium concentration was $0.06 \mathrm{mM}$ as determined by flame photometry.

\section{Incorporation of $\left[{ }^{14}\right.$ C]acetate into lipids}

Confluent cell cultures (culture dishes, $35 \mathrm{~mm}$ diameter) were incubated for $30 \mathrm{~h}$ in culture media supplemented with 5\% lipoprotein-deficient serum or 5\% fetal calf serum [8]. For medsurement of de novo lipid synthesis, $\left[{ }^{14} \mathrm{C}\right]$ acetate (Amersham International, Amersham, U.K., $59 \mathrm{mCi} / \mathrm{mM}, 2.5$ $\mu \mathrm{Ci} / \mathrm{ml}$ ) at a final concentration of $0.5 \mathrm{mM}$ was added after which the cells were incubated for 18 h. All incubations were performed at $37^{\circ} \mathrm{C}$ in humidified atmosphere containing $10 \% \mathrm{CO}_{2}$. Next, the medium was removed and the cells were trypsinized, washed three times with phosphatebuffered saline, and divided into three fractions. Two of these were extracted with chloroform/ methanol $(1: 2)(\mathrm{v} / \mathrm{v})$ mixture according to Bligh and Dyer [22]. Organic phases were dried under a stream of $\mathrm{N}_{2}$ gas at $30^{\circ} \mathrm{C}$. The third fraction was lysed in $1 \mathrm{M} \mathrm{NaOH}$ after which an aliquot was taken for protein determination [23]. The lipids of one portion of the cell extracts were separated into different neutral lipid classes by one-dimensional thin-layer chromatography on silica gel plates (Merck) using chloroform/methanol $(98: 2)$ as the first and hexane/chloroform $(3: 1)$ as the second developing system. Development was performed in the presence of authentic standards, i.e., cholcstcrol, oleic acid, cholesterol oleate and triolein (Sigma). The second portion of the cell ex- 
tract was used for phospholipid separation using high-performance thin-layer chromatography plates (Merck) and developing system of chloroform/methanol/acetic acid $/ \mathrm{H}_{2} \mathrm{O}(100: 60: 6: 4)$, and in the presence of authentic standards, i.e., phosphatidylcholine, phosphatidylethanolamine, phosphatidylserine, phosphatidylinositol and sphingomyelin (Sigma). Lipid fractions were visualized by iodine vapor and, after destaining, were scraped off and counted for radioactivity using Picofluor (Packard) as scintillation fluid.

The values given in the figures are the means of two or three independent experiments performed in duplicate. The average standard error of the mean was between 10 and $15 \%$.

\section{Results}

\section{Effect of extracellular lipoproteins on total lipid synthesis}

The cells were exposed to lipoprotein-deficient serum at least $30 \mathrm{~h}$ before lipid synthesis was measured. As shown in Fig. 1, in the absence of extracellular lipoproteins keratinocytes cultured under normal $\mathrm{Ca}^{2+}$ conditions exhibit a 1.3-fold higher acetate incorporation into the total lipid fractions as compared to cells cultured under low $\mathrm{Ca}^{2+}$ conditions. Furthermore, cells grown under low $\mathrm{Ca}^{2+}$ conditions exhibit a 2-fold decrease in acetate incorporation into total lipids upon exposure to extracellular lipoproteins. This difference is smaller, approximately 1.2-fold, in cells grown under normal $\mathrm{Ca}^{2+}$ conditions. Finally, comparison of low $\mathrm{Ca}^{2+}$ with normal $\mathrm{Ca}^{2+}$ cells demonstrates a 2-fold higher rate of lipid synthesis in the latter, when the keratinocytes were exposed to extracellular lipoproteins (Fig. 1).

Under low $\mathrm{Ca}^{2+}$ conditions the rate of lipid synthesis differed markedly in the three squamous carcinoma cell lines, with the highest rate in poorly differentiating SCC- 4 cells, an intermediate rate in SCC-15 cells and the lowest rate in well-differentiating SCC-12F2 cells, irrespective of the presence or absence of external lipoproteins (Fig. 1A). The presence of external lipoproteins leads to the suppression of lipid synthesis to a slight extent in all cell lines. A similar pattern has been observed in all cell lines grown under normal $\mathrm{Ca}^{2+}$ conditions (Fig. 1B), although the presence of external

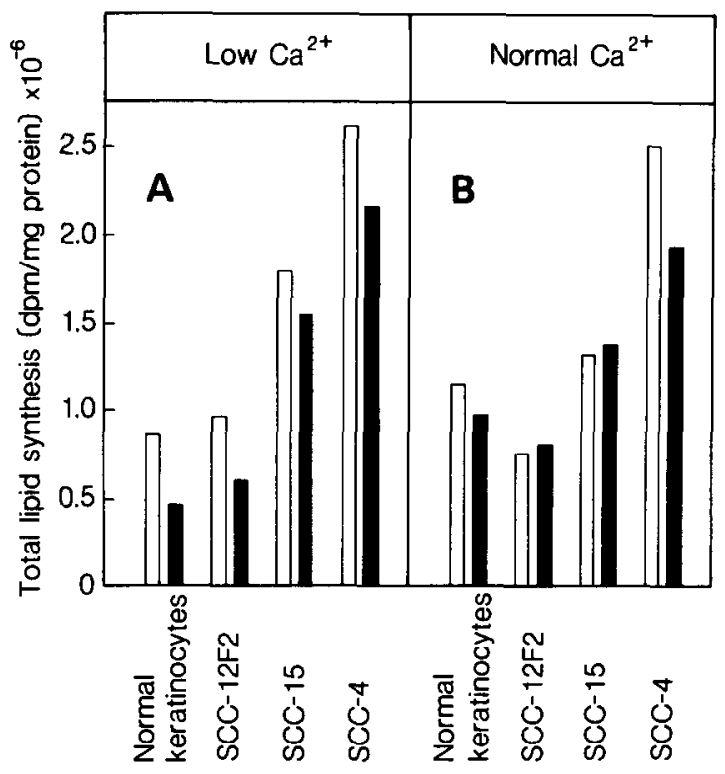

Fig. 1. Calcium-induced effects on the de novo lipid synthesis in confluent cultures of human epidermal keratinocytes and squamous carcinoma cells. The confluent cultures of normal keratinocytes, SCC-12F2, SCC-15, and SCC-4 cells grown either at a low $(0.06 \mathrm{mM})(\mathrm{A})$ or a normal $(1.6 \mathrm{mM})$ (B) calcium level were preconditioned for $30 \mathrm{~h}$ in medium supplemented with either $5 \%$ lipoprotein-deficient serum or $5 \%$ fetal calf serum. For the measurement of the de novo lipid synthesis, $\left[{ }^{14} \mathrm{C}\right]$ acetate $(2.5 \mu \mathrm{Ci} / \mathrm{ml}, 0.5 \mathrm{mM})$ was added and the cells were incubated for $18 \mathrm{~h}$. Subsequently, the incorporation of $\left[{ }^{14} \mathrm{C}\right]$ acetate into various lipid fractions was measured after the extraction of lipids and their separation by TLC, as described in Materials and Methods. Unfilled bars, without extra cellular lipoproteins; filled bars, with extracellular lipoproteins.

lipoproteins does not lead to the suppression of lipid synthesis in SCC-15 and SCC-12F2 cells.

These results demonstrate a clear effect of the presence of external lipoproteins on total lipid synthesis, except for SCC-12F2 and SCC-15 under normal $\mathrm{Ca}^{2+}$ conditions and, in addition, a correlation between lipid synthesis and differentiation capacity of the cells.

Analysis of $\left[{ }^{14} \mathrm{C}\right]$ acetate incorporation into the phospholipid and neutral lipid fractions demonstrates that both phospholipid and neutral lipid synthesis progressively increases in the order normal keratinocytes $\leq$ SCC-12F $2<$ SCC-15 $<$ SCC4 , in cells cultured in the presence or absence of extracellular lipoproteins under low $\mathrm{Ca}^{2+}$ conditions (Fig. 2A,B). A similar phenomenon is observed in the absence of extracellular lipoproteins 


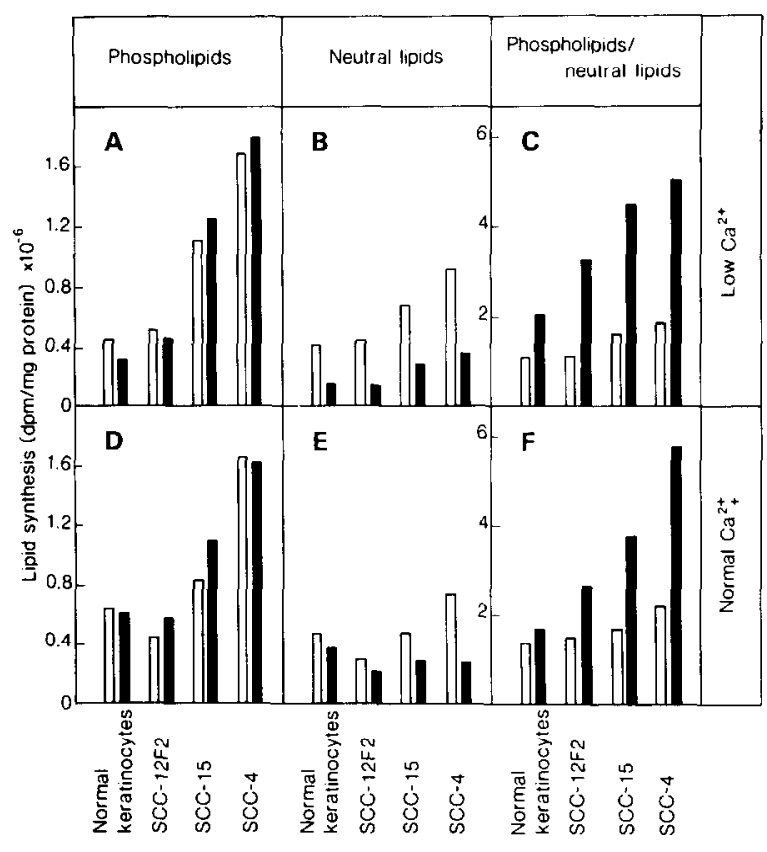

Fig. 2. Effect of culture conditions on phospholipid and neutral lipid synthesis. The incorporation of $\left[{ }^{14} \mathrm{C}\right]$ acetate into phospholipids and neutral lipids was measured as described in Fig. 1, and the ratio of $\left[{ }^{14} \mathrm{C}\right]$ acetate incorporated into phospholipids and neutral lipids was calculated. Unfilled bars, without extracellular lipoproteins; filled bars, with extracellular lipoproteins.

in the SCC lines grown under normal $\mathrm{Ca}^{2+}$ conditions (Fig. 2D,E) and for phospholipid synthesis in the presence of extracellular lipoproteins (Fig. 2D), but is not found for neutral lipid synthesis in the presence of extracellular lipoproteins in cells grown under normal $\mathrm{Ca}^{2+}$ conditions (Fig. 2E). Furthermore, normal keratinocytes exhibit a significantly higher rate of phospholipid and neutral lipid synthesis under normal $\mathrm{Ca}^{2+}$ conditions (Fig. $2 \mathrm{D}, \mathrm{E}$ ) as compared to SCC-12F2 cells.

The effect of external lipoproteins on lipid synthesis in the four cell types under both $\mathrm{Ca}^{2+}$ conditions is more clearly demonstrated by calculation of the phospholipid-neutral lipid ratio (Fig. 2C,F). Under both $\mathrm{Ca}^{2+}$ conditions, the ratio is considerably increased in the presence of external lipoproteins, mainly due to a decrease in neutral lipid synthesis. Furthermore, again, under all conditions, the ratio exhibits an increasing order: normal keratinocytes < SCC-12F2 < SCC-15 < SCC-4 (Fig. 2C,F).
Effect of extracellular lipoproteins on phospholipid synthesis

In contrast to the rate of neutral lipid synthesis, the rate of phospholipid synthesis is not significantly affected by the presence of external lipoproteins in all four cell types (Fig. 2A,D). Analysis of $\left[{ }^{14} \mathrm{C}\right]$ acetate incorporation into the various phospholipid fractions reveals that most of the acetate is incorporated into the phosphatidylcholine fraction (Table I). The presence or absence of external lipoproteins causes no major changes in the phospholipid synthesis pattern.

\section{Effect of extracellular lipoproteins on neutral lipid synthesis}

In all four cell types, under both $\mathrm{Ca}^{2+}$ conditions, the rate of neutral lipid synthesis is decreased in the presence of external lipoproteins (Fig. 2B,E). The effect is more pronounced under low than under normal $\mathrm{Ca}^{2+}$ concentrations, where it is highest in SCC-4 and lowest in SCC-12F2 cells and normal keratinocytes.

Analysis of $\left[{ }^{14} \mathrm{C}\right]$ acetate incorporation into the neutral lipid classes is shown in Fig. 3. The presence of external lipoproteins severely suppresses cholesterol synthesis (Fig. 3A) and increases the cholesterol ester synthesis (Fig. 3C) in all cell lines grown under low $\mathrm{Ca}^{2+}$ conditions. A similar effect, although less pronounced, is observed for cholesterol synthesis in SCC-4 and SCC-15 cells grown under normal $\mathrm{Ca}^{2+}$ conditions, but no such effect is observed in SCC-12F2 cells and normal keratinocytes (Fig. 3E). Cholesterol ester synthesis is not affected by external lipoproteins in SCC-15, SCC-12F2 cells and normal keratinocytes and is only slightly stimulated in SCC-4 cells after culturing under normal $\mathrm{Ca}^{2+}$ concentrations (Fig. 3G). The effect of external lipoproteins on cholesterol and cholesterol ester synthesis in the four cell lines under both $\mathrm{Ca}^{2+}$ conditions is more clearly demonstrated by calculation of cholesterol/cholesterol ester ratio (Fig. 3D,H). Under both $\mathrm{Ca}^{2+}$ conditions, the ratio is considerably decreased in the presence of extracellular lipoproteins, the only exception being SCC-12F2 cells and normal keratinocytes grown under normal calcium conditions. Triacylglycerol synthesis is suppressed in the presence of external lipoproteins in all cell lines, most significantly in SCC-12F2 and normal keratino- 
TABLE I

RELATIVE DISTRIBUTION OF $\left[{ }^{14}\right.$ C]ACETATE INCORPORATION INTO VARIOUS PHOSPHOLIPID FRACTIONS IN NORMAL KERATINOCYTES, SCC-12F2, SCC-15 AND SCC-4 CELLS CULTURED UNDER LOW (0.06 mM) AND NORMAL (1.6 mM) $\mathrm{Ca}^{2+}$ CONDITIONS IN THE PRESENCE OR ABSENCE OF EXTRACELLULAR LIPOPROTEINS

$\left[{ }^{14} \mathrm{C}\right]$ Acetate incorporation into phospholipids was determined as described under Materials and Methods. The data from normal keratinocytes were obtained using cells from five different skin donors. S, sphingomyelin; PC, phosphatidylcholine; PE, phosphatidylethanolamine; PS, phosphatidylserine; PI, phosphatidylinositol. The data represent the mean values \pm S.E. of at least three independent experiments performed in duplicate.

\begin{tabular}{|c|c|c|c|c|c|c|c|c|}
\hline \multirow{3}{*}{$\begin{array}{l}\text { Extracellular } \\
\text { lipoproteins }\end{array}$} & \multicolumn{8}{|c|}{$\left[{ }^{14} \mathrm{C}\right]$ Acetate incorporation into phospholipids (\%) } \\
\hline & \multicolumn{2}{|c|}{ normal keratinocytes } & \multicolumn{2}{|l|}{ SCC-12F2 } & \multicolumn{2}{|l|}{ SCC-15 } & \multicolumn{2}{|l|}{ SCC-4 } \\
\hline & - & + & - & + & - & + & - & + \\
\hline \multicolumn{9}{|l|}{ Low $\mathrm{Ca}^{2+}$} \\
\hline $\mathrm{S}$ & $10.4 \pm 2.4$ & $7.7 \pm 1.4$ & $13.7 \pm 8.4$ & $10.9 \pm 1.0$ & $7.6 \pm 0.6$ & $5.3 \pm 0.7$ & $7.8 \pm 0.2$ & $6.7 \pm 0.6$ \\
\hline PC & $58.4 \pm 2.4$ & $60.6 \pm 1.4$ & $55.2 \pm 1.3$ & $58.0 \pm 0.9$ & $66.6 \pm 0.7$ & $67.0 \pm 1.5$ & $64.6 \pm 1.8$ & $64.4 \pm 1.4$ \\
\hline PE & $16.2 \pm 2.6$ & $14.4 \pm 1.2$ & $16.5 \pm 1.4$ & $15.8 \pm 1.4$ & $12.0 \pm 0.8$ & $12.4 \pm 0.5$ & $11.2 \pm 0.5$ & $11.8 \pm 0.5$ \\
\hline PS & $5.5 \pm 1.0$ & $6.2 \pm 2.0$ & $5.5 \pm 1.0$ & $6.6 \pm 0.7$ & $4.5 \pm 0.9$ & $5.5 \pm 0.8$ & $4.5 \pm 0.6$ & $5.8 \pm 1.2$ \\
\hline PI & $9.4 \pm 1.0$ & $11.1 \pm 2.0$ & $9.2 \pm 0.2$ & $8.8 \pm 0.2$ & $9.4 \pm 0.1$ & $9.8 \pm 0.1$ & $11.9 \pm 0.8$ & $11.3 \pm 0.5$ \\
\hline \multicolumn{9}{|l|}{ Normal $\mathrm{Ca}^{2+}$} \\
\hline $\mathbf{S}$ & $11.4 \pm 2.3$ & $10.9 \pm 1.6$ & $16.2 \pm 0.7$ & $15.3 \pm 0.6$ & $10.9 \pm 8.6$ & $8.9 \pm 0.1$ & $9.9 \pm 0.8$ & $8.7 \pm 0.4$ \\
\hline PC & $58.4 \pm 2.4$ & $57.7 \pm 2.6$ & $53.2 \pm 0.7$ & $53.9 \pm 0.9$ & $60.7 \pm 0.2$ & $61.2 \pm 0.3$ & $61.2 \pm 0.9$ & $60.2 \pm 1.1$ \\
\hline PE & $14.8 \pm 1.0$ & $14.7 \pm 1.4$ & $15.9 \pm 1.7$ & $15.5 \pm 1.7$ & $14.4 \pm 1.0$ & $15.0 \pm 1.6$ & $12.8 \pm 0.5$ & $13.8 \pm 0.2$ \\
\hline PS & $6.5 \pm 0.7$ & $7.5 \pm 1.4$ & $5.7 \pm 0.7$ & $6.4 \pm 0.5$ & $5.3 \pm 0.8$ & $5.8 \pm 0.5$ & $5.2 \pm 0.1$ & $6.2 \pm 0.3$ \\
\hline PI & $8.9+0.7$ & $9.3 \pm 1.4$ & $9.0 \pm 0.5$ & $8.8 \pm 0.4$ & $8.8+0.3$ & $9.1+0.6$ & $10.9+0.7$ & $11,1+0.7$ \\
\hline
\end{tabular}

cytes (Fig. 3B). A comparable effect is observed in cells grown under normal $\mathrm{Ca}^{2+}$ conditions (Fig. $3 F)$.

In normal keratinocytes using the two-dimensional separation of lipids [24] the $\left[{ }^{14}\right.$ C]acetate incorporation into ceramides, important lipid compounds of the differentiating epidermis [2428 ], is found to be $2-3 \%$, suggesting that under the culture conditions used only a low extent of keratinocyte maturation occurs (data not shown).

Effect of external calcium on de novo lipid synthesis Culturing normal keratinocytes in media with a low $\mathrm{Ca}^{2+}$ concentration results in a suppression of the differentiation capacity and adaptation of a typical cell morphology [16]. Raising the extracellular $\mathrm{Ca}^{2+}$ concentration to levels higher than 0.1 $\mathrm{mM}$ causes a rapid change of cell morphology, until the morphology is comparable to that of cells continuously exposed to normal $\mathrm{Ca}^{2+}$ levels (Fig. 4). An increase of the extracellular $\mathrm{Ca}^{2+}$ concentration from 0.06 to $0.1 \mathrm{mM}$ leads to a clear increase in the rate of lipid synthesis and reaches a maximum at an external $\mathrm{Ca}^{2+}$ concentration of
$0.2 \mathrm{mM}$ (Fig. 5). The relative incorporation of $\left[{ }^{14} \mathrm{C}\right]$ acetate into the phospholipid fraction is not significantly influenced by variations of the external $\mathrm{Ca}^{2+}$ concentrations (Table II). It should be realized that the absolute value of phospholipid synthesis increases at increasing external $\mathrm{Ca}^{2+}$ concentrations, comparable to the rate of total lipid synthesis (Fig. 5). A clear decrease of the relative acetate incorporation into the triacylglycerol and cholesterol ester fractions, accompanied by an increase into the cholesterol fractions is observed (Table II). The dependency of the rate of lipid synthesis upon the external $\mathrm{Ca}^{2+}$ concentrations, especially the rate of cholesterol synthesis, coincides with the dependency on the ability of keratinocytes to form cornified envelopes and to the change of their morphology.

A similar relationship between the external $\mathrm{Ca}^{2+}$ concentration and lipid synthesis is observed by exposing keratinocytes grown under low $\mathrm{Ca}^{2+}$ (0.06 $\mathrm{mM})$ concentrations, towards normal (1.6 $\mathrm{mM}) \mathrm{Ca}^{2+}$ concentrations. As shown previously, a shift of the $\mathrm{Ca}^{2+}$ concentration from low to normal values is accompanied by an increase in the 


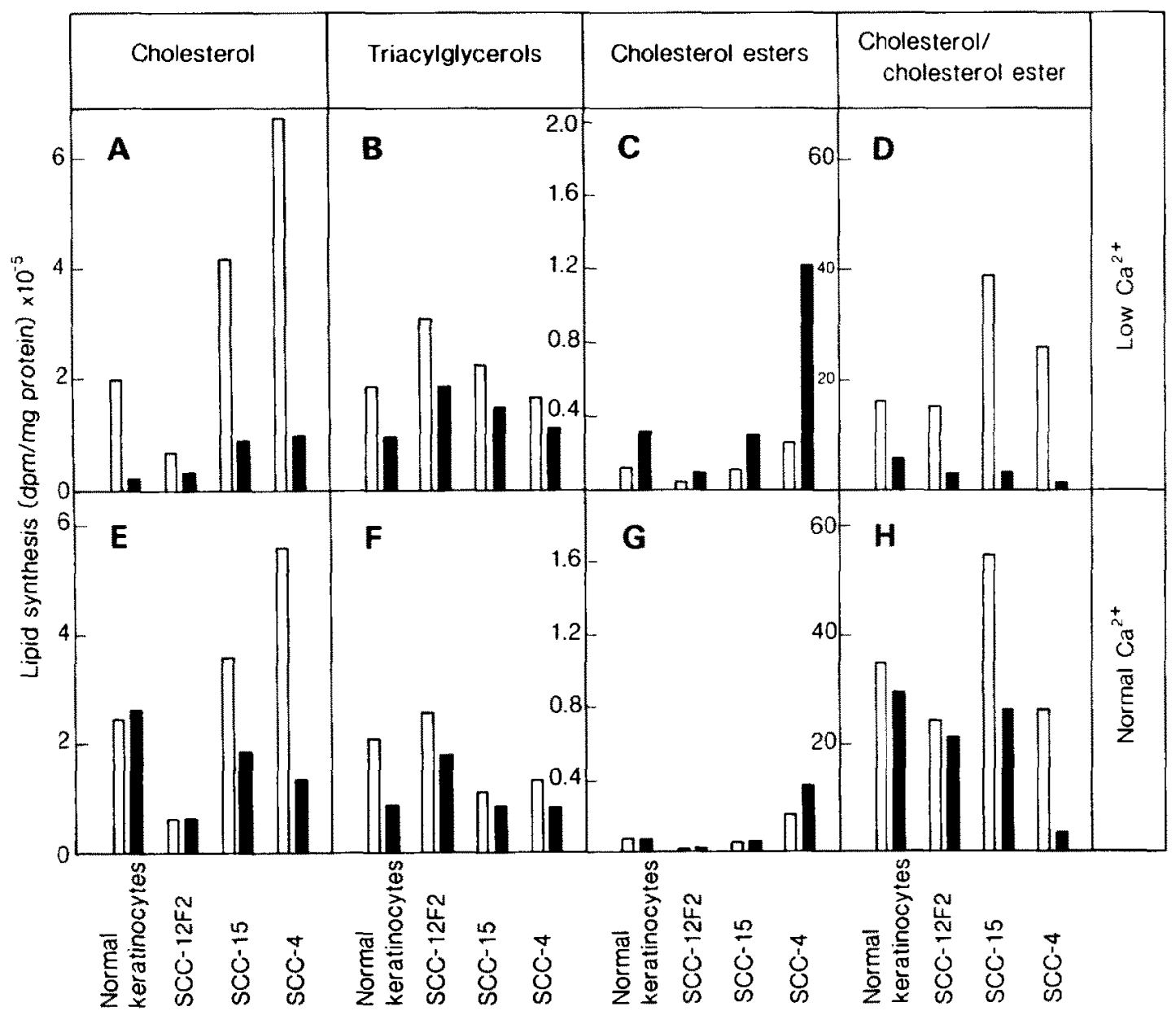

Fig. 3. Effect of culture conditions on the synthesis of cholesterol, triacylglycerols and cholesterol esters. The incorporation of $\int^{14}$ Clacetate into cholesterol $(A, E)$, triacylglycerols $(B, F)$ and cholesterol esters $(C, G)$ was measured as described in Fig. 1, and the ratio of $\left[{ }^{14}\right.$ Clacetate incorporated into cholesterol and cholesterol esters was calculated $(D, H)$. Unfilled bars, without extracellular lipoproteins; filled bars: with extracellular lipoproteins.
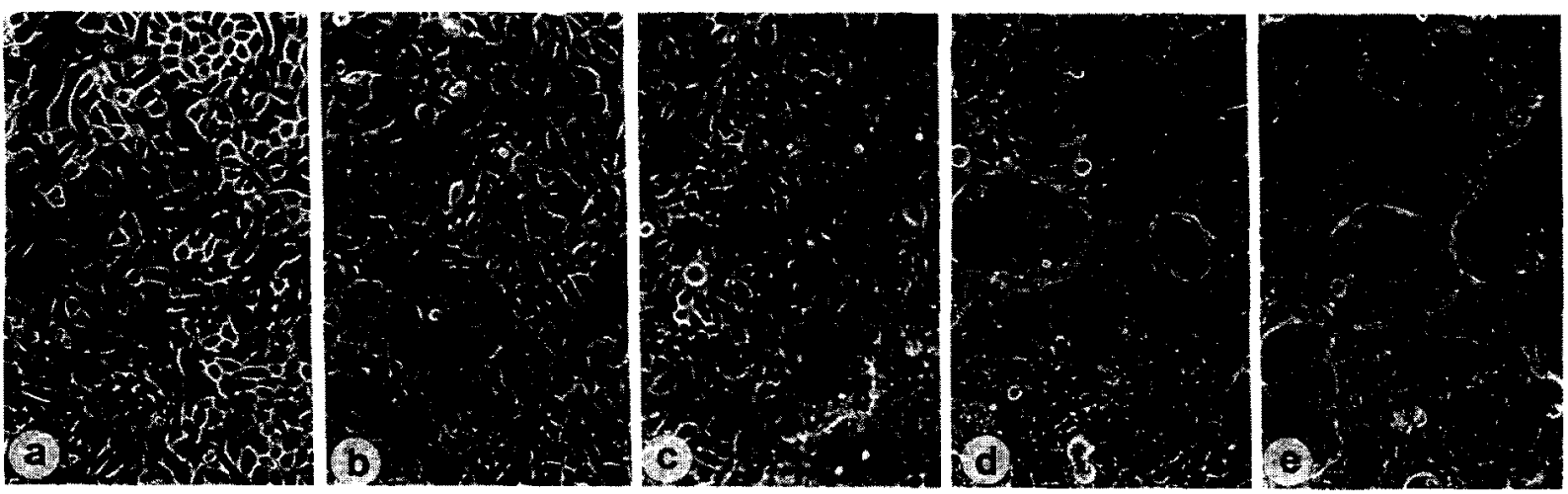

Fig. 4. Phase contrast photographs of normal human keratinocytes. The cells were grown to confluency at $0.06 \mathrm{mM} \mathrm{Ca}^{2+}$ concentration and incubated for 3 days in media containing (a) $0.06 \mathrm{mM}$, (b) $0.1 \mathrm{mM}$, (c) $0.14 \mathrm{mM}$, (d) $0.2 \mathrm{mM}$, and (e) $1.6 \mathrm{mM}$ $\mathrm{Ca}^{2+}$ concentrations. At $0.06 \mathrm{mM} \mathrm{Ca}{ }^{2+}$, the cells show a refractile appearance and have a polygonal shape with definitive intercellular spaces. At $\mathrm{Ca}^{2+}$ concentrations above $0.1 \mathrm{mM}$ the cell culture is less refractile with smaller boundaries between the cells. Stratification is observed at $\mathrm{Ca}^{2+}$ concentrations of $0.2 \mathrm{mM}$ and higher. 


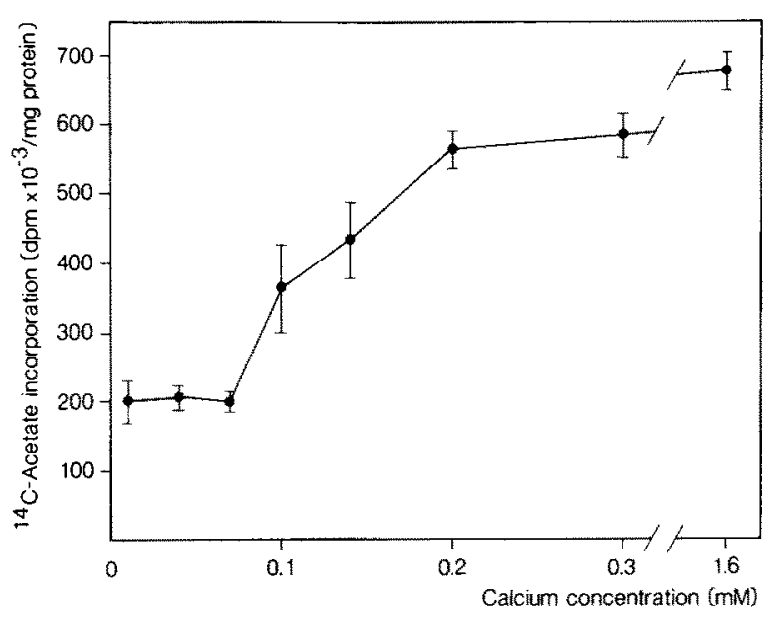

Fig. 5. Effect of external $\mathrm{Ca}^{2+}$ concentration upon $\left[{ }^{14} \mathrm{C}\right] \mathrm{acetate}$ incorporation into total lipids. The cells grown to confluency at $0.06 \mathrm{mM} \mathrm{Ca}^{2+}$ concentration were further incubated for 3 days in media containing various $\mathrm{Ca}^{2+}$ concentrations. Subsequently, the cells were reincubated for $18 \mathrm{~h}$ in identical media to which $\left[{ }^{14} \mathrm{C}\right.$ ]acetate $(2.5 \mu \mathrm{Ci} / \mathrm{ml}, 0.5 \mathrm{mM})$ was added and the

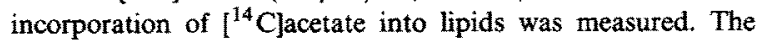
values given in the figure are means \pm S.D. of two independent experiments, each of them performed in duplicate.

ability of the cells to form cornified envelopes [8]. As shown in Fig. 6, the initiation of differentiation induced by the $\mathrm{Ca}^{2+}$ shift is accompanied also by a rapid increase in the rate of lipid synthesis. Analysis of the $\left[{ }^{14} \mathrm{C}\right]$ acetate incorporation into the various lipid fractions demonstrates large modulations of cholesterol biosynthesis after the $\mathrm{Ca}^{2+}$ shift. During the first $10 \mathrm{~h}$ after the $\mathrm{Ca}^{2+}$ shift, the rate of cholesterol synthesis remains unchanged, followed by a rapid increase obtained $50 \mathrm{~h}$ after the $\mathrm{Ca}^{2+}$ shift. In addition, a rapid increase is found in the rate of acetate incorporation into the free fatty acid and triacylglycerol fractions, while a similar rapid decrease is observed in the rate of cholesterol ester biosynthesis. Furthermore, an increase is measured in the rate of phospholipid synthesis, most clearly in sphingomyelin and only to a slight extent in phosphatidylinositol and phosphatidylserine synthesis. As such, these data are in agreement with those presented in Table II, and strongly suggest a correlation between lipid synthesis and keratinocyte differentiation capacity.

\section{Discussion}

The results presented in this paper show that the rate of lipogenesis is closely related to the ability of cells to differentiate, being highest in poorly differentiating $\mathrm{SCC}-4$ cells, intermediate in moderately differentiating SCC-15 cells and lowest in well-differentiating SCC-12F2 cells and normal keratinocytes (Fig. 1). Both the rate of phospholipid and neutral lipid synthesis, as well as the phospholipid-neutral lipid ratio decreased in the same rank order (Fig. 2), except for normal keratinocytes grown under normal $\mathrm{Ca}^{2+}$ conditions. Also, for the synthesis of individual phospholipids

TABLE II

\section{EFFECT OF EXTERNAL Ca ${ }^{2+}$ CONCENTRATION UPON $\left[{ }^{14} \mathrm{C}\right]$ ACETATE INCORPORATION INTO VARIOUS LIPIDS}

The cells grown to confluency at $0.06 \mathrm{mM} \mathrm{Ca}^{2+}$ concentration were further incubated for 3 days in media containing various $\mathrm{Ca}^{2+}$ concentrations. Subsequently, the cells were reincubated for $18 \mathrm{~h}$ in identical media to which [ ${ }^{14} \mathrm{Clacetate}(2.5 \mu \mathrm{Ci} / \mathrm{ml}, 0.5 \mathrm{mM})$ was added and the incorporation of $\left[{ }^{14}\right.$ Clacetate into various lipid fractions was measured. The values given in the table are means \pm S.D. of two independent experiments, each of them performed in duplicate.

\begin{tabular}{llllll}
\hline $\begin{array}{l}\text { Concn. } \\
\mathrm{Ca}^{2+} \\
(\mathrm{mM})\end{array}$ & \% of ${ }^{14} \mathrm{C}$-acetate incorporation into: & & \\
\cline { 2 - 6 } & phospholipids & free fatty acids & cholesterol & triacylglycerols & cholesterol esters \\
\hline 0.01 & $68.8 \pm 2.2$ & $0.8 \pm 0.1$ & $3.0 \pm 1.5$ & $19.8 \pm 2.7$ & $7.6 \pm 1.6$ \\
0.04 & $68.2 \pm 1.8$ & $0.7 \pm 0.1$ & $2.2 \pm 0.2$ & $21.0 \pm 3.7$ & $7.9 \pm 1.4$ \\
0.07 & $67.2 \pm 3.9$ & $0.5 \pm 0.1$ & $2.8 \pm 1.1$ & $21.1 \pm 2.2$ & $8.0 \pm 0.9$ \\
0.10 & $67.7 \pm 4.2$ & $0.4 \pm 0.2$ & $15.7 \pm 2.7$ & $15.5 \pm 1.8$ & $0.4 \pm 0.09$ \\
0.14 & $68.6 \pm 1.7$ & $0.5 \pm 0.1$ & $16.9 \pm 2.9$ & $13.7 \pm 1.4$ & $0.3 \pm 0.07$ \\
0.20 & $65.1 \pm 2.2$ & $0.5 \pm 0.1$ & $20.3 \pm 3.1$ & $13.8 \pm 1.3$ & $0.2 \pm 0.05$ \\
0.30 & $65.9 \pm 3.6$ & $0.5 \pm 0.1$ & $20.1 \pm 2.8$ & $13.2 \pm 1.7$ & $0.3 \pm 0.04$ \\
1.6 & $63.2 \pm 4.8$ & $0.3 \pm 0.1$ & $23.0 \pm 4.2$ & $13.1 \pm 2.0$ & $0.2 \pm 0.03$ \\
\hline
\end{tabular}




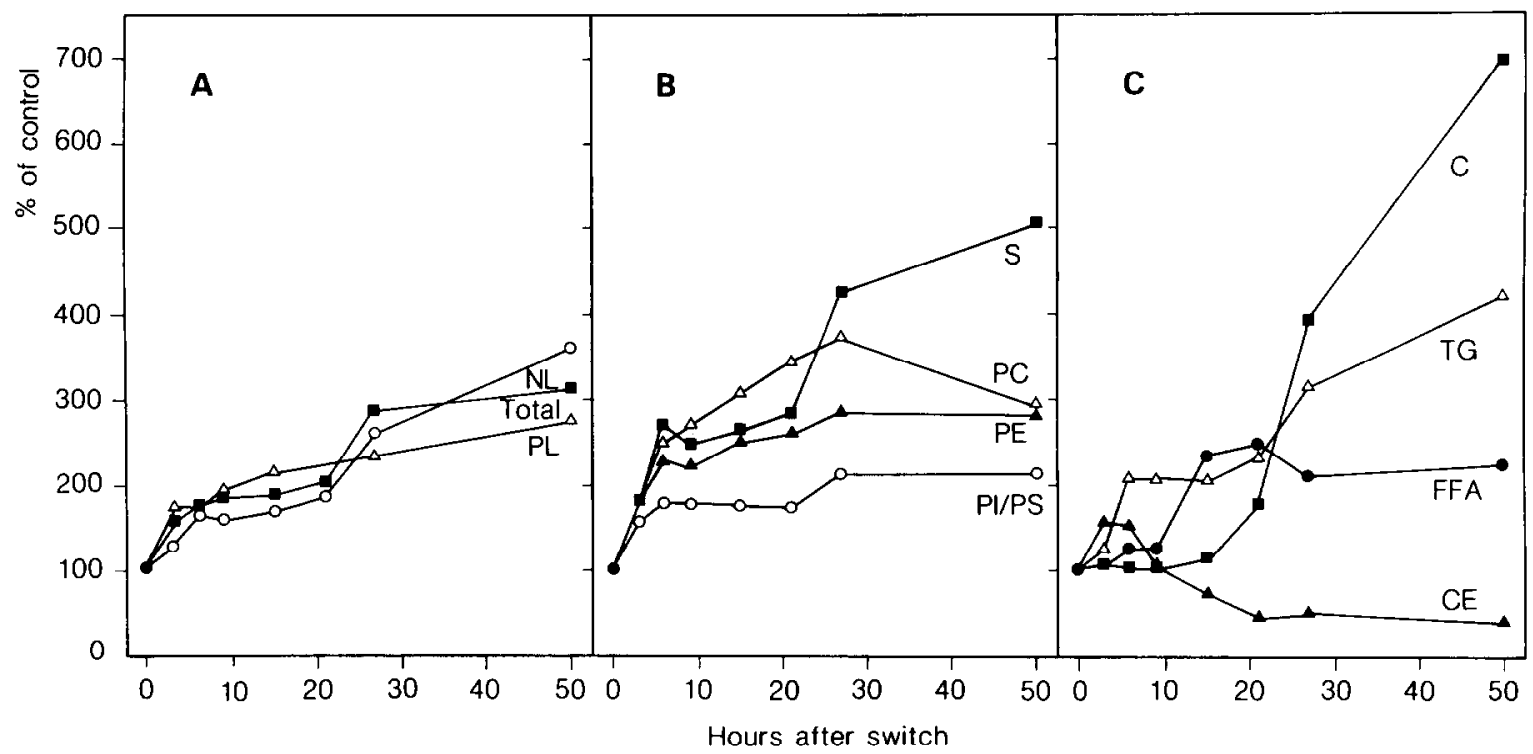

Fig. 6. Time course of calcium-induced changes of de novo lipid synthesis. The confluent cultures of keratinocytes grown at low calcium $(0.06 \mathrm{mM})$ concentration and in the presence of $5 \%$ fetal calf serum were incubated for various time intervals in medium containing calcium at a normal $(1.6 \mathrm{mM})$ concentration. The cells were exposed for $2 \mathrm{~h}$ to $\left[{ }^{14} \mathrm{C}\right]$ acetate $(12.5 \mu \mathrm{Ci} / \mathrm{ml}, 0.5 \mathrm{mM})$ before the amount of $\left[{ }^{14} \mathrm{C}\right]$ acetate incorporated into various lipid fractions was determined. The amount of incorporated $\left[{ }^{14} \mathrm{C}\right]$ acetate was expressed per mg cellular protein. As a control the incorporation of $\left[{ }^{14} \mathrm{C}\right]$ acetate into cells incubated at low calcium concentration was used. Values given in the figure are the means of two experiments, each of them performed in triplicate. A. Incorporation of $\left[{ }^{14}\right.$ C]acetate into total lipids $(\square)$, neutral lipids (NL) $(O)$ and phospholipids (PL) $(\triangle)$. B, incorporation of $\left[{ }^{14} \mathrm{C}\right]$ acetate into various phospholipid fractions (sphingomyelin (S) ( $\square$ ), phosphatidylcholine (PC) ( $\triangle$ ), phosphatidylinositol and phosphatidylserine (PI/PS) (O), phosphatidylethanolamine (PE) (A)). C, incorporation of $\left[{ }^{14} \mathrm{C}\right]$ acetate into various neutral lipid fractions (free fatty acids (FFA)

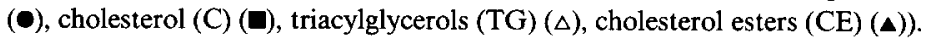

and neutral lipids, the same rank order was observed, the only exceptions being the synthesis of triacylglycerols (the rate of which increased with the increasing ability of the cells to differentiate) and the cholesterol synthesis in normal keratinocytes (which was higher than that in SCC-12F2 cells) (Fig. 3).

Similar to normal keratinocytes that exhibit a relatively high level of LDL receptor expression and a high rate of LDL metabolism under low calcium conditions [8], in all three squamous carcinoma cells grown under low $\mathrm{Ca}^{2+}$ conditions the rate of neutral lipid synthesis was also clearly suppressed by the presence of extracellular lipoproteins, to a similar extent in all three cell lines. Under normal $\mathrm{Ca}^{2+}$ conditions, however, the extent of suppression of neutral lipid synthesis by extracellular lipoproteins was inversely related to the ability of cells to differentiate (Fig. 2).

In all cell types in which the LDL-receptor uptake system is operative, the free cholesterol derived from LDL inhibits the de novo cholesterol synthesis and increases cholesterol esterification [4]. Also, in cells in which the LDL-receptor uptake mechanism is operative, the rate of cholesterol synthesis is significantly decreased and that of cholesterol ester increased in the presence of extracellular lipoproteins. This observation holds for all cell types grown under low $\mathrm{Ca}^{2+}$ conditions, and for SCC-4 and to a lesser extent for SCC-15 cells grown under normal $\mathrm{Ca}^{2+}$ conditions. No significant changes were observed in the rate of cholesterol or of cholesterol ester synthesis in either normal keratinocytes or SCC-12F2 cells, due to the low extent of LDL-receptor expression and LDL metabolism [6].

Next to a number of similarities existing between the mechanisms controlling the differentiation-induced modulation of lipid synthesis between normal keratinocytes and squamous carcinoma cells some differences have been observed. Compared to squamous carcinoma cells, the rate 
of lipid synthesis in the presence of extracellular lipids in normal keratinocytes cultured under low $\mathrm{Ca}^{2+}$ conditions was suppressed to a higher extent due to the suppression of both the neutral lipid and the phospholipid synthesis (Figs. 1,2). However, at a low $\mathrm{Ca}^{2+}$ level the rate of phospholipid synthesis in squamous carcinoma cells was not significantly modulated by extracellular lipoproteins (Fig. 2A). Furthermore, in normal keratinocytes a higher rate of total lipid synthesis was observed in cells grown under normal $\mathrm{Ca}^{2+}$ conditions, as compared to cells grown under low $\mathrm{Ca}^{2+}$ conditions, irrespective of the presence or absence of extracellular lipoproteins. No such differences were seen in squamous carcinoma cells. At present we have no explanation for these differences.

In all cells under study, irrespective of the $\mathrm{Ca}^{2+}$ concentration in the culture medium, the rate of triacylglycerol synthesis was suppressed by extracellular lipoproteins, suggesting that the triacylglycerol synthesis is a subject of a different feedback mechanism than the synthesis of cholesterol and cholesterol esters, since this decrease was most pronounced in SCC- $12 \mathrm{~F} 2$ cells and in normal keratinocytes in which no feedback of cholesterol synthesis by extracellular LDL cholesterol was observed.

Induction of differentiation by exposure of cells grown under low $\mathrm{Ca}^{2+}$ conditions to media containing gradually increasing $\mathrm{Ca}^{2+}$ concentrations is accompanied with a loss of the LDL-receptor activity [8]. The loss of LDL-receptor activity, which occurs within $25 \mathrm{~h}$ after $\mathrm{Ca}^{2+}$ shift [8], is accompanied by the loss of the response of cells to changes of extracellular lipid composition. This finding suggests that differentiating epidermal cells, that show the autonomy of lipogenesis, possess a unique mechanism controlling lipid metabolism, so far not found in other cell types.

It has been well established that profound changes in lipid composition have been observed during differentiation of keratinocytes in the epidermis; especially an increase in cholesterol and ceramide content and decrease in phospholipid content have been described [24-28]. The increase in cholesterol content is in agreement with the data presented in this paper. The acetate incorporation into ceramide fractions was found to be low in cultured keratinocytes, irrespective of the exter- nal $\mathrm{Ca}^{2+}$ concentrations. These observations indicate that cultured human and mouse [29] keratinocytes do not approach the same degree of maturation as obtained in vivo [27].

From the results obtained it is clear that a close inverse relationship exists between the regulation of lipogenesis by extracellular lipoproteins and the ability of cells to differentiate. This may offer the possibility for selective administration of drugs incorporated into LDL using a lipoprotein-mediated uptake mechanism for treatment of squamous cell carcinomas having decreased ability to differentiate and, in this way, to modulate their proliferation and differentiation.

\section{References}

1 De Laat, S.W., Bluemink, J.G., Boonstra, J., Mummery, C.L., Van der Saag, P.T. and Van Zoelen, E.J.J. (1984) in Physiology of Membrane Fluidity, Vol. 2 (Shinitsky, M., ed.), pp. 21-51, CRC Press, Boca Raton, FL

2 Ponec, M., Tertoolen, L.G.J. and De Laat, S.W. (1986) J. Invest. Dermatol. 87, 162

3 Ponec, M., Kempenaar, J., Weerheim, A. and Boonstra, J. (1987) J. Cell. Physiol., in the press

4 Brown, M.S. and Goldstein, J.L. (1976) Science 191, 150-154

5 Ponec, M., Havekes, L., Kempenaar, J. and Vermeer, B.J. (1981) J. Invest. Dermatol. 81, 125-130

6 Ponec, M., Havekes, L., Kempenaar, J. and Vermeer, B.J. (1984) J. Invest. Dermatol. 83, 436-440

7 Ponec, M., Lavrijsen, S., Kempenaar, J., Havekes, L. and Boonstra, J. (1985) J. Invest. Dermatol. 85, 476-482

8 Ponec, M., Havekes, L., Kempenaar, J., Lavrijsen, S., Wijsman, M., Boonstra, J. and Vermeer, B.J. (1985) J. Cell Physiol. 125, 98-106

9 Ponec, M. and Kempenaar, J. (1985) J. Invest. Dermatol. 84,452

10 Hawley-Nelson, P., Sullivan, J.E., Kung, M., Hennings, H. and Yuspa, S.H. (1980) J. Invest. Dermatol. 75, 176-182

11 Hennings, H.D., Michael, D., Cheng, C., Steinert, P., Holbrook, K. and Yuspa, S.H. (1980) Cell 19, 245-254

12 Hennings, H.D., Holbrook, K.A. and Yuspa, S.H. (1983) J. Cell Physiol. 116, 265-281

13 Watt, F.M. and Green, H. (1982) Nature 295, 434-436

14 Brysk, M.M., Miller, J. and Walker, G.K. (1984) Exp. Cell. Res. 150, 329-337

15 Swieringa, S.H.H., Auersperg, N. and Wong, K.S. (1983) Cancer Res. 43, 6012-6020

16 Boonstra, J., De Laat, S.W. and Ponec, M. (1985) Exp. Cell Res. 161, 421-433

17 Malmqvist, K.G., Carsson, L.E., Forslind, B., Roomans, G.M. and Akselsson, K.R. (1984) Nuclear Instruments and Methods in Physics Research B3, 61-617

18 Rheinwald, J.G. and Beckett, M.A. (1980) Cell 22, 629-632 
19 Rheinwald, J.G. and Beckett, M.A. (1981) Cancer Res. 41, 1657-1663

20 Rheinwald, J.G. and Green, H. (1975) Cell 6, 331-344

21 Brennan, J.K., Mansky, J., Roberts, G. and Lichtman, M.A. (1975) In Vitro 11, 354-360

22 Bligh, E.G. and Dyer, W.J. (1959) Can. J. Biochem. Physiol. 37, 911-917

23 Lowry, O.H., Rosebrough, N.J., Farr, A.L. and Randall, A.L. (1951) J. Biol. Chem. 193, 265-275

24 Nugteren, D.H., Christ-Hazelhof, E., Van der Beek, A. and Hautsmuller, U.M.T. (1985) Biochim. Biophys. Acta 842, 429-436
25 Gray, G.M. and Yardley, H.J. (1975) J. Lipid Res. 16, $441-447$

26 Yardley, H.J. and Summerly, R. (1981) Pharmacol. Ther. 13, 357-383

27 Elias, P.M. (1983) J. Invest. Dermatol. 80, 445-495

28 Wertz, P.W. and Downing, D.T. (1983) J. Lipid Res. 24, 759-765

29 Madison, K.C., Wertz, P.W., Strauss, J.S. and Downing, D.T. (1986) J. Invest. Dermatol. 87, 253-259 